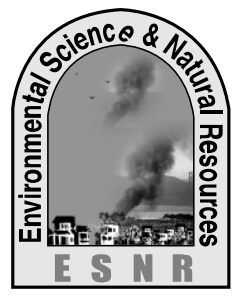

J. Environ. Sci. \& Natural Resources, 5(2): 181 - 184, 2012

ISSN 1999-7361

\title{
Prevalence of PPR of Goat and Their Response to Antibiotic Treatment at Mirzaganj Upazila of Patuakhali Distrtict
}

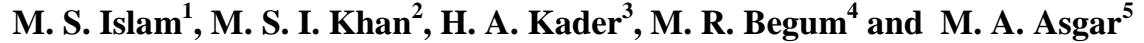 \\ ${ }^{1}$ Department of Post-harvest Technology and Marketing, ${ }^{2}$ Department of Food Microbiology, ${ }^{3}$ Department \\ of Human Nutrition and Dietetics, ${ }^{5}$ Department of Physiology, Biochemistry and Pharmacology; \\ Patuakhali Science and Technology University \\ ${ }^{4}$ Department of Agricultural Economics and Social Science, Chittagong Veterinary and Animal Sciences \\ University.
}

\begin{abstract}
The study was conducted at Upazila Livestock Office from $1^{\text {st }}$ January to $31^{\text {th }}$ March, 2010 to observe the prevalence of PPR in goat at Mirzaganj upazila in Patuakhali District. A total of 183 goats were examined based on the clinical signs and gross pathological lesions of which 92 were PPR affected makes up 50.27\%. After categorizing the animals according to their breed, age and vaccination history it was revealed that Black Bengal goats were more susceptible (54.93\%) than Jamunapari $(31.38 \%)$. The prevalence of PPR was maximum $63.33 \%$ at age category of $7-12$ months, in compare with $44.68 \%$, $41.87 \%$, $45.45 \%$ at age category of $\leq 6$ months, $13-18$ months and $\geq 19$ months respectively. Non-vaccinated goats were more susceptible $(66.40 \%)$ to PPR infection than vaccinated goats $(19.56 \%)$. Parental (I/M) Oxytetracycline was more effective $(64 \%)$ than parental (I/M) Sulphadimidine (44\%) along with symptomatic treatment. PPR causes higher mortality and heavy economic losses in every year which may be reduced substantially by proper vaccination and other managemental approaches.
\end{abstract}

Key words: Black bengal goat, Clinical signs, Jamunapari, Prevalence, PPR.

\section{Introduction}

Goat rearing is an integral part of farming system in Bangladesh and the population of goat is about 33.51 million (DLS, 2002) which put $3.96 \%$ contribution in GDP (Alam et al., 1998). The animal is particularly useful for low-income farmers, landless labourers and distress women who cannot afford to rear cattle. Hence, goat is called "The cow of poor people" in Bangladesh. Goat rearing provides a significant level of supplying animal protein in the form of meat $(20 \%)$, and one of the important areas of earning foreign exchange through the exportation of skin. But there are several diseases of goat especially PPR, which cause higher mortality and great economic losses. PPR is an exotic disease of goats in Bangladesh (Debnath, 1995; Islam et al., 2001).

Sheep and Goats are the natural host of PPR virus whereas goats are more susceptible than sheep (Radostits et al., 2000). PPR has been recognized to a highly contagious viral disease of small ruminants, particularly in goats in Bangladesh (Islam et al., 2001). The disease clinically resembles Bovine rinderpest and is characterized by high fever, necrotic stomatitis, catarrhal inflammation of the ocular and nasal mucosae, pneumonia, diarrhoea and death (Fraser, 1986). In epidemic areas, morbidity rate has been estimated from $80 \%$ to $90 \%$ accompanied by mortality rate range from $50 \%$ to $80 \%$ (Debnath, 1995).
It is caused by paramyxovirus of morbillivirus genus and first described in 1942 in Cote De Ivoire. Also reported from the African continental, in the Arabian peninsula, certain countries of the Middle East and South Asia (Taylor et al., 1990). In Bangladesh, the presence of rinderpest like disease in goats was first detected by FAO expert team during their visit in western districts of the country in 1993. Later, the causal agent of the disease was identified as PPR virus by World Reference laboratory (Barrette et al., 1997).It is assumed that $75 \%$ of the districts in Bangladesh ate affected with PPR in Bangladesh it is thought that the disease might have come from India (Debnath, 1995). Rainy season is more susceptible to occur the disease as compared with dry season (Samad, 1996). Transmission occur by close contact, inhalation of aerosol produced by sneezing and coughing of infected animals, direct contact with ocular, nasal, oral secretions, feces, fomites such as bedding, water and feed troughs (Ozkul, 2002).

PPR like other viral diseases of have no specific treatment for PPR, however mortality may be decreased by using drugs that control the bacterial complications (Taylor et al., 1984). Also, combined drug therapy can save the animal in field condition (Richrd and Adams, 1996). The present study was conducted to determine the prevalence of PPR disease and the response of animals to the antibiotic treatment in the study area. 


\section{Materials and Methods}

To determine prevalence of PPR in goat diseased animals was brought to the hospital for treatment were examined. Information on all types of diseases including breed, age, vaccination history, owners complain, body condition of the patients and given treatment were recorded for the study.

\section{Population and tools used for data collection}

The study was conducted on natural PPR infected goats of various age, sex and breed that were brought to the hospital over the study period. A total of 183 cases of goats were recorded of those PPR were detected in 92 cases.

\section{Anamnesis}

History of the cases was taken from the owner and carefully recorded in each case individually.

\section{Clinical examination}

The flowing clinical examinations were done carefully and the findings were recorded.

\section{Close inspection}

Close inspection were performed properly in order to observe the presenting signs such as a sharp rise of temperature of $104^{\circ} \mathrm{F}-106^{\circ} \mathrm{F}$, occulonasal discharge, diarrhea and respiratory distress.

\section{Temperature recorded}

Per rectal temperature was recorded with the thermometer in every case.

\section{Indirect auscultation}

Respiratory distress was identified with the help of stethoscope and the lung and tracheal sound were observed and recorded.

\section{Clinical signs of PPR}

Sudden high fever $\left(104^{\circ} \mathrm{F}-106^{\circ} \mathrm{F}\right)$, oculo-nasal discharge, difficult breathing, non haemorrhagic diarrhea, rough hair coat, characteristic foul smell from mouth, Anorexia, depression, severe dehydration and emaciation followed by hypothermia. Lining of mouth become pale and sometimes membrane become obscure due to cheesy material (Samad, 1996)

\section{Follow up treatment}

For observing the treatment efficacy the goats were divided into two groups. Combined therapy Diadin ( Sulphadimidine-Na) + Dellergen (Promethazine Hcl) $+\quad$ Renalyte(ORS) and Renamycin-100 (Oxytetracycline) + Dellergen (Promethazine Hcl)+ Renalyte(ORS) was given in separete groups.

\section{Results and Discussion}

The study was conducted among the naturally infected PPR goats of various ages and sex that were brought to the hospital. A total of 183 animals examined where 92 goats were affected with PPR constituting $50.27 \%$.

The Prevalence \% of PPR in relation to breed of goats are summarized in Table 1. The Prevalence of PPR disease was higher in Black Bengal goat $(54.93 \%)$ than in Jamunapari goat $(31.78 \%)$. This result is similar to the report of Samad (2000) where Black Bengal goat are more $(67.24 \%)$ susceptible to PPR than Jamunapari (32.76\%).

Table 1. Prevalence in relation to breeds of goat

\begin{tabular}{l|l|l|l|l}
\hline Name of the breed & No. of PPR cases & No. of other cases & Total cases & Prevalenance (\%) \\
\hline Black Bengal & 78 & 64 & 142 & 54.93 \\
Jamunapari & 13 & 28 & 41 & 31.78 \\
\hline
\end{tabular}

The prevalenance of PPR in relation to different age categories is present in Table 2. The prevalence of PPR was maximum $63.33 \%$ at age category 7-12 months, in compare with $44.68 \%, 41.87 \%, 45.45 \%$ at age category $\leq 6$ months, $13-18$ months and $\geq 19$ months respectively. It agrees with the study of Blood et al., (1995) where prevalence was maximum within 7-8 months of age. 
Table 2. Prevalence relative to different age categories

\begin{tabular}{l|l|l|l|c}
\hline $\begin{array}{l}\text { Age groups } \\
\text { (Months) }\end{array}$ & No. of PPR cases & No. of other cases & Total no. of cases & $\begin{array}{c}\text { Prevalenance } \\
(\%)\end{array}$ \\
\hline$\leq 6$ & 21 & 26 & 47 & 44.68 \\
$7-12$ & 38 & 22 & 60 & 63.33 \\
$13-18$ & 18 & 25 & 43 & 41.87 \\
$\geq 19$ & 15 & 18 & 33 & 45.45 \\
\hline
\end{tabular}

The Prevalence of PPR in relation to immune status is illustrated in Table 3. The prevalence of PPR is higher $(66.40 \%)$ in non-vaccinated as compare with vaccinated $(19.56 \%)$ animals. This result support the earlier report of Gibbs et al., (1979) where higher prevalence of PPR was found in the unvaccinated goat population.

Table 3. Prevalence in relation to immune status

\begin{tabular}{l|l|l|l|l}
\hline Immune status & No. of PPR cases & No. of other cases & Total no cases & Prevalence (\%) \\
& & \multicolumn{3}{|c}{} \\
\hline Vaccinated & 9 & 37 & 46 & 19.56 \\
Non- vaccinated & 83 & 53 & 125 & 66.40 \\
\hline
\end{tabular}

The relative effects of drugs in treatment of PPR are presented in table 5 . The percentage response of treatment towards parenteral ( $\mathrm{I} / \mathrm{M}$ ) Oxytetracycline was higher (64\%) than parenteral (I/M) Sulphadimidine (44\%). This is similar to the report of
Taylor et al., (1984) where mortality rates may be decreased by the use of drugs that control the bacterial complications especially oxytetracycline and Chlortetracycline are recommended to prevent secondary pulmonary infections.

Table 4. Response to treatment in relation to different drugs

\begin{tabular}{|c|c|c|c|}
\hline $\begin{array}{c}\text { Drug name } \\
\text { (Trade + Generic) }\end{array}$ & Response to treatment & Total & $\%$ of response \\
\hline 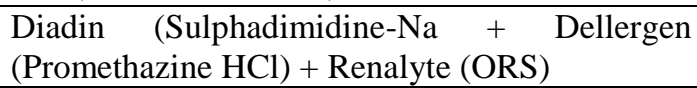 & 11 & 25 & 44 \\
\hline $\begin{array}{l}\text { Renamycin-100 (Oxytetracycline) + Dellergen } \\
(\text { Promethazine } \mathrm{HCl})+\text { Renalyte }(\text { ORS })\end{array}$ & 16 & 25 & 64 \\
\hline
\end{tabular}

\section{Conclusions}

It is observed that Black Bengal goats were more susceptible to PPR than Jamunapari goats. Between 7-12 months of age was more risky for the infection and the infection of goats can be reduced markedly by proper vaccination program. It was observed that, Oxytetracycline (I/M) was more effective than Sulphadimidine (I/M) to reduce the mortality. PPR causes heavy economic losses in every year especially in rainy seasons and also decreases the productive performances of goat. So, Proper surveillance and regular vaccination program should be taken to eradicate the disease.

\section{References}

Alam, J. S.; Rahman, A.; Sayeed, M. A. 1998. A study on Livestock Credit in Rural Bangladesh. Bangladesh Journal of Livestock Research. 1:15-18.

Barrete, T.; Pronab, D.; Sreenivasa, B. P. and Corteyn, M. 1997. Recent epidemiology of peste des petits ruminants virus (PPRV). Veterinary Microbiology. 88: 125-130.

Blood, D. C.; Rodostis, O. M. and Gay, C. C., 1995. Veterinary Medicine. $8^{\text {th }}$ Edn. Ballier Tindall, UK: 837.

Debnath, N. C. 1995. Peste des petits ruminants (PPR); an overview proceeding of the BSVER 
Symposium on Eradication of Rinderpest and Related Diseases. $2^{\text {nd }}$ December, 1995, Dhaka; 9-13.

Fraser, C. M. 1986. Peste des petits ruminants (PPR). The Merck Veterinary Manual. $6^{\text {th }}$ edition, Merck and Co. Inc. U. S. A; 402-403.

Gibbs, E. P. J.; Taylor, W. P.; Lawman, M. J. P. 1979. Classification of Peste des petits ruminants (PPR) virus as the fourth member of the genus Morbilivirus Intervirology. 15:35-41.

Islam, M. R.; Shamsuddin, M.; Das, P. M. and Dewan, M. L. 2001. An outbreak of Peste des petits ruminants in Black Bengal goats in Mymensingh, Bangladesh. The Bangladesh Veterinarian., 18(1): 14-19.

Ozkul, A.; Akea, Y.; and Alkan, F. 2002. Prevalence, distribution, and host range of peste des petits ruminants virus, Turkey. Emerg Infect Dis.; 8(7): 708-712.

Radostis, O. M.; Blood, D. C. and Gay, C. C. 2000. Veterinary Medicine. $9^{\text {th }}$ edn, Bailliere and Tindall, London.
Richard, A. B.; Adams, B. K. and Ambumani, S. P. 1996. Peste des petits ruminents in Tamilnadu goats. Indian veterinary journal., 73:587-588.

Samad, M. A. 1996. Poshu Palon O Chikitsavidya (Animal Husbandry and Medicine). Published by M. Bulbul, Bangladesh Agricultural University campus, Mymenshingh,Bangladesh.

Samad, M. A. 2000. Poshu Palon O Chikitsavidya (Animal Husbandry and Medicine). $2^{\text {nd }}$ Edn., Published by M. Bulbul, Bangladesh Agricultural University campus, Mymenshingh, Bangladesh.

Taylor, W. P. 1984. The distribution and epidemiology of peste des petits ruminants. Preventive Veterinary Medicine, 2: 157-166.

Taylor, W. P.; Al Busaidy, S. Barrett, T. 1990. The epidemiology of peste des petits ruminants in the Sultanate of Oman, Veterinary Microbiology., 22 (4): 341-352. 